Institute of $\mathbf{F}_{\text {ood and }} \mathbf{A}_{\text {gricultural }} \boldsymbol{S}_{\text {ciences }}$

\title{
Florida Crop/Pest Management Profile: Guava and Wax Jambu $^{1}$
}

Mark A. Mossler \& O. Norman Nesheim²

\section{Production Facts}

- Guava (Psidium guajava) and wax jambu (Syzygium samarangense) are both tropical plants in the Myrtaceae (1).

- In 1990, acreage of guava in Florida approached 80 acres. By the middle of the decade, this fruit was grown on nearly 200 acres (2).

- The 1995-1996 average yield of guava in Florida was 25,000 pounds per acre. At a packout rate of 70 percent and a price of $\$ 1.15$ per pound, the Florida crop was worth approximately $\$ 3$ million (2).

- In 1995-1996, there were at least two acres of wax jambu in production (3).

- Guava varieties include "Supreme", "Ruby", "Blitch", "Miami Red", "Miami White", "Red Indian", and "Patillo." Wax jambu varieties include "Pink" and "Srinark" $(1,4)$.

\section{Production Regions}

Guava and wax jambu are grown exclusively in southern Florida. In 1996, 99 percent of the guava acreage and 100 percent of the wax jambu acreage were located in Miami-Dade County (3).

\section{Production Practices}

The guava tree is small (six to 20 feet), with broad, spreading tops, branching freely close to the ground. The trunk is short with a scaly bark, greenish to light brown in color (4). The tree is native to the American tropics, and it is believed to be introduced to Florida from Cuba in 1847 (2). Leaves are oblong and opposite, three to seven inches in length, with prominent veins on the bottom leaf surface. This side of the leaf is also finely pubescent when leaves are young. Flowers are white, approximately one inch in diameter, and borne singly or in small clusters. Fruit may range from one ounce to two pounds in weight. Skin color varies from light green to yellow, and the pulp may be white, yellow, pink, or red. Fruit ranges

1. This document is CIR 1415, one of a series of the Pesticide Information Office, Food Science and Human Nutrition Department, Florida Cooperative Extension Service, Institute of Food and Agricultural Sciences, University of Florida. For additional Information, contact the Pesticide Information Office, University of Florida, P. O. Box 110710, Gainesville, Fl 32611-0710, (352) 392-4721. Published August 2002 Please visit the EDIS Web site at http://edis.ifas.ufl.edu

2. Mark A. Mossler, Pest Management Information Specialist. O. Norman Nesheim, Ph.D., Professor and Pesticide Coordinator, Pesticide Information Office, Food Science and Human Nutrition Department, Cooperative Extension Service, Institute of Food and Agricultural Sciences, University of Florida, Gainesville, 32611-0710.

The use of trade names in this publication is solely for the purpose of providing specific information. UF/IFAS does not guarantee or warranty the products named, and references to them in this publication does not signify our approval to the exclusion of other products of suitable composition. All chemicals should be used in accordance with directions on the manufacturer's label.

The Institute of Food and Agricultural Sciences is an equalopportunity/affirmative action employer authorized to provide research, educational information and other services only to individuals and institutions that function without regard to race, color, sex, age, handicap, or national origin. For information on obtaining other extension publications, contact your county Cooperative Extension Service office. Florida Cooperative Extension Service / Institute of Food and Agricultural Sciences / University of Florida / Christine Taylor Waddill, Dean 
from thin-shelled, with many seeds embedded in a firm pulp to thick-shelled with few seeds. Flavor ranges from sweet to highly acidic, and the aroma may be strong and penetrating or mild and pleasant. The guava tree blooms continuously throughout the year, fruit requires about 120 days to mature, and peak harvest runs from August through October, with a minor harvest in February and March (4).

Wax jambu is a native of the Malay Archipelago (5). The tree is 16 to 50 feet tall with a short trunk. The fruit is pear-shaped, waxy, and approximately two inches long and two inches wide at the waist. The fruit skin may be white, red, or pink, with a spongy white flesh. A single seed is present in the center. The tree flowers during April and May and fruit are harvested from June through July (1).

Guava trees may be propagated by conventional methods. Although seed is used, varieties do not reproduce true to type. Consequently, vegetative propagation is used. Air-layering is the easiest method, but is impractical when large numbers of plants are needed and the source of material is limited. Veneer grafting and chip budding are successful only when seedling rootstocks are young and vigorous and the scion comes from terminal growth which is green and quadrangular. Leafy stem cuttings root successfully in a mist bed. Properly propagated and cultured trees may start to bear within two or four years, and a mature tree will produce from 120 to 220 pounds of fruit per year. Selfpollination is possible in guava. However, crosspollination by insects results in higher yields (4).

Susceptibility to cold weather restricts guava growing in Florida to the southern portion of the state. Small trees may be killed by temperatures of $27-28^{\circ} \mathrm{F}$. Older trees can withstand short periods of temperature as low as $25-26^{\circ} \mathrm{F}$ without much damage.

Under Florida conditions, guava plantings are spaced 10 or 20 feet in-row and 20 to 25 feet between trees ( 87 to 217 trees per acre). Guava trees also respond well to pruning. Pruning hastens flowering and fruiting by promoting vigorous flushes of mixed growth (i.e. leaves and flowers). Mechanical pruning is often done after the peak harvest, after the trees have been picked between two and six times (6).

\section{Insect/Mite Management}

\section{Insect/Mite Pests}

The principal pests on guava in Florida are redbanded thrips, Caribbean fruit fly, guava moth, and guava whitefly. Scale insects may also intermittently infest guava plantings $(4,7)$.

\section{Redbanded Thrips (Selenothrips}

rubrocinctus). The redbanded thrips is ubiquitous in its distribution throughout Florida, but it is generally found in damaging numbers from Orlando to Key West. Female redbanded thrips are slightly greater than $1 \mathrm{~mm}$ in length, and has a dark brown to black body underlain by red pigment, chiefly in the first three abdominal segments. The larvae is light yellow to orange, with the first three and last segments of the abdomen bright red. The life cycle of this thrips is about three weeks in Florida, and several generations are possible each year. In addition to attacking tropical fruit trees (guava, avocado, and mango), this thrips also attacks sweetgum trees. Redbanded thrips prefer young foliage, which may lead to leaf drop, at times totally denuding trees. Infested leaves are spotted on the upper surface with fecal deposits that turn reddish brown to black. The russetting from thrips feeding results in fruit which is out-of -grade (8).

\section{Caribbean Fruit Fly (Anastrepha suspensa).} This fly is also referred to as the guava fruit fly or Greater Antilliean fruit fly. The fly is indigenous to the West Indies and aggressively attacks guava and Surinam cherry in its range. In Florida, this fly was absent from the late 1930s until 1965, when a large outbreak occurred near Miami. Since that time, the fly has continued to spread and it now occurs in most of southern Florida, commonly north to Citrus and Volusia counties. The Caribbean fruit fly has become the main fruit fly problem for citrus and several other crops in Florida, including guava.

The fly is about the size of a housefly, and yellow-brown in color. The wings are yellow to yellow-brown as well and have a pattern of black markings. The fly only infests mature to overripe fruit. Eggs are laid singly and hatch in two to three 
days. Larval feeding occurs for ten to 14 days, and pupation lasts an equal amount of time.

Since 1990, a joint federal/state program has been implemented that rears an endoparasitic braconid wasp, Diachasmimorpha longicaudata. This wasp deposits eggs in the pupa of the fruit fly, which feed on the fly as they develop. Trapping results reflect a 40 percent reduction in fruit fly numbers with this plan in operation. Additionally, millions of sterile flies are produced and released yearly in a sterile insect technique program (9).

\section{Guava Moth (Argyresthia eugeniella).} Although not as damaging as the Caribbean fruit fly, the larvae of this moth spoil ripe fruit by tunneling through it. The larvae are whitish in color with a black head. They become pink as they approach maturity and attain a length of nearly one-quarter inch (8).

Guava Whitefly (Metaleurodicus cardini). This insect is also known as Cardin's whitefly. This whitefly has been identified in Florida since 1917, from southern Florida as far north as Gainesville. However, it is much more common in the subtropical areas of the state. Guava whitefly is usually innocuous, but under conditions that disrupt the parasite/predator complex, it can become a damaging pest.

The adult guava whitefly is greenish yellow with a fine dusting of white wax. The wings are dusky with a conspicuous dark spot near the center of each wing. As females deposit eggs, a fine trail of fluffy white wax is rubbed from a tuft of wax on the ventral side of the abdomen (10).

\section{Chemical Control}

In 1999-2000, 40 percent of responding surveyed guava growers reported insecticide use. No insecticide use was reported by wax jambu growers. Those survey respondents that provided an insect damage estimate indicated that up to 90 percent of the guava crop would be lost to insect damage $(n=1)$. For wax jambu, this figure was estimated to be 95 percent $(\mathrm{n}=1)$.
Insecticides and miticides registered for use on Florida guava include azadirachtin (Azatin $\left.{ }^{\circledR}\right)$, Beauveria bassiana (Mycotrol $\left.{ }^{\circledR}\right)$, Bacillus thuringiensis, fenoxycarb (Logic $₫$ - for ants on nonbearing trees only), spinosad (SpinTor $\left.{ }^{\circledR}\right)$, malathion, pyrethrin + rotenone (Pyrellin $\left.{ }^{\circledR}\right)$, pyrethrin, crop oil, and insecticidal soap. Insecticides available for wax jambu include crop oil, insecticidal soap, azadirachtin, spinosad (SpinTor $\left.{ }^{\circledR}\right)$, Beauveria bassiana, and Bacillus thuringiensis.

Malathion. Malathion is an organophosphate compound which causes death by interfering with proper nerve transmission. Based on survey response, malathion is mainly used to manage Caribbean fruit fly. The median price of malathion is $\$ 5.44$ per pound of active ingredient and the approximate cost per application is $\$ 4.08$ per acre $(11,12)$. The preharvest interval (PHI) is 2 days and the restricted entry interval (REI) is 12 hours (12). The label also recommends that the application be made in conjunction with one pound of partially hydrolyzed yeast protein or enzymatic yeast hydrolyzate per acre. In 1999-2000, 40 percent of surveyed guava growers applied malathion to their acreage ten times (50 percent) or 24 times (50 percent) for an average use of 17 times per season.

\section{Alternative Control}

At least one "reduced impact" insecticide has been registered for use on guava and wax jambu. Mycotrol ${ }^{\circledR}$ (Beauveria bassiana) is just now being assessed for insect management in this crop.

\section{Cultural Control}

Based on survey results of all tropical fruit growing respondents, 44 percent reported keeping records of pest problems, 50 percent adjusted applications (timing or rate) to protect beneficial insects and mites, and 52 percent alternated pesticides to reduce resistance. Sixty-two percent reported selecting the pesticide that is least toxic to beneficial insects and mites and 63 percent spot sprayed only infested plants or areas. Seventy percent reported selecting pesticides that are least toxic to the 
environment to make this the dominant form of cultural pest control.

\section{Biological Control}

Seven percent of the responding tropical fruit growers reported release of predatory wasps for control of lepidopteran pests. Additionally, 30 percent reported the use of biological-derived pesticides like B.t.

\section{Weed Management}

\section{Weed Pests}

Weeds can reduce yields to tree crops by competing mainly for water and nutrients. Although individual weed species may vary from region to region within the state, predominant weed species in groves are often grasses, sedges, and pigweeds (13). However, species composition is less important as the trend has been toward use of non-selective, postemergent herbicides.

\section{Chemical Control}

In 1999-2000, 80 percent of surveyed guava growers and 100 percent of wax jambu growers reported herbicide use. There are nine herbicides labeled for use on guava (glyphosate, paraquat, atrazine, oryzalin, sulfosate, oxyfluorfen, pelargonic acid, and fluazifop). Fluazifop and sulfosate are only registered for non-bearing guava. The only herbicide available for wax jambu is glyphosate. All of these herbicides are used to control weeds between and around trees. Non-selective herbicides include glyphosate (Roundup $\left.{ }^{\circledR}\right)$, paraquat (Gramoxone ${ }^{\circledR}$ ), pelargonic acid (Scythe ${ }^{\circledR}$ ), and sulfosate (Touchdown ${ }^{\circledR}$ ). All of these are post-emergence herbicides. Selective herbicides include atrazine, fluazifop (Fusilade ${ }^{\circledR}$ ), oxyfluorfen (Goal $\left.{ }^{\circledR}\right)$, and oryzalin (Surflan $\left.{ }^{\circledR}\right)$. All of these are pre-emergence compounds except fluazifop-p-butyl, which is a postemergence herbicide (14).
Glyphosate (Roundup ${ }^{\circledR}$ ). Glyphosate is a phosphorylated amino acid herbicide used for total vegetation control (14). Glyphosate is applied as a directed spray so that foliage is not injured. The median price of glyphosate is $\$ 10.95$ per pound of active ingredient and the approximate cost per application is $\$ 21.90$ per acre for annual weeds and $\$ 54.75$ per acre for perennial weeds $(11,15)$. The PHI for glyphosate is 24 hours (guava) or 14 days (wax jambu) and the REI is 4 hours (16).

In 1999-2000, 80 percent of surveyed guava growers in Florida applied glyphosate either three (25 percent), four ( 50 percent), or six ( 25 percent) times for an average use of 4.3 times per season. One hundred percent of wax jambu growers applied glyphosate for weed control (number of times used was unspecified).

\section{Disease Management Disease Pathogens}

The principal diseases affecting guava production in Florida include fungi and a parasitic algae. Anthracnose (Colletotrichum gloeosporioides) and leaf spot (Cercospora and Pseudocercospora spp.) are fungal diseases which affect guava production. Algal spot (Cephaleuros virescens) may become apparent in summer and sooty mold is often present, though not considered a true disease of guava. Nonmanageable diseases include mushroom root rot (Armillaria tabescens) and thread blight (Rhizoctonia solani). These diseases are controlled by selecting proper planting areas and pruning out diseased tissue, respectively (17).

Anthracnose (caused by Colletotrichum gloeosporioides). The fungus attacks young shoots, leaves and immature fruit. Shoots develop a typical dieback during moist periods. Young leaves exhibit large, irregular necrotic leaf spots that during moist periods form pinkish spore masses. The fungus infects green fruit causing circular brown-to-black colored lesions that enlarge. The zones of pinkish sporulation can often be observed on the fruit as well (17). 
Algal Spot (caused by Cephaleuros virescens). Algal spot has a wide host range among tropical trees. Lesions on leaves are roughly circular, raised, and purple to reddish-brown in color. The alga will eventually produce rust-colored microscopic "spores" on the surface of the leaf spots, giving them a reddish appearance. The alga may also spread to branches and fruit. Fruit spots are slightly raised, dark-green to black, $2 \mathrm{~mm}$ in diameter, with irregular margins. Fruit may also crack at the lesion sites (17).

Leaf Spot (caused by Cercospora and Pseudocercospora spp.). Infection appears as dark smokey patches on the lower leaf surface which are not sharply defined. The fungi reproduce abundantly from the lower leaf surface (17).

\section{Chemical Control}

In 1999-2000, 40 percent of surveyed guava and 100 percent of wax jambu growers reported fungicide use. Those survey respondents that provided damage estimates indicated that 10 percent of the guava crop would be lost to disease $(n=1)$. Wax jambu growers only reported a 15 percent loss from disease. The only registered fungicide for use on guava is copper, in the form of copper hydroxide, copper sulfate, metallic copper, or copper oxide.

Copper (Kocide $\left.{ }^{\circledR}\right)$. Copper has long been used as a fungicide and can be applied in multiple forms. Copper is used to manage anthracnose and algal spot. The median price of copper hydroxide is $\$ 2.11$ per pound of active ingredient and the approximate cost per application is $\$ 4.87$ per acre $(11,18)$. The PHI and REI for copper hydroxide are 0 day and 24 hours, respectively (18).

In 1999-2000, 40 percent of surveyed guava growers in Florida applied copper (in some form) either two (50 percent), or three (50 percent) times for an average use of 2.5 times per season.

\section{Alternative Control}

Based on work by IR-4, tolerances for guava and wax jambu have been obtained for the fungicide azoxystrobin as of September, 2001. This material will assuredly be assessed for disease management in these crops.

\section{Nematode Management}

\section{Nematode Pests}

Plant-parasitic nematodes are microscopic roundworms, found in soils, which primarily attack plant roots. General signs of nematode damage include stunting, premature wilting, leaf yellowing, root malformation, and related signs characteristic of nutrient deficiencies. Stunting and poor stand development tend to occur in patches throughout the field as a result of the irregular distribution of nematodes within the soil. Species of nematodes reported to be associated with guava trees include Rotylenchulus reniformis, Radopholus similis, Hemicriconemoides mangiferae, and Meloidogyne (M. incognita, M. arenaria, M. javanica, and $M$. hapla). All four of these root-knot species are widespread and cause considerable damage to guava tree roots $(19,20)$.

\section{Chemical Control}

There are no currently registered nematicides for use on guava or wax jambu. None of the surveyed guava or wax jambu growers reported the use of nematicides.

\section{Key Contacts}

- Jonathan Crane is an associate professor of horticultural science located at the Tropical Research and Education Center in South Florida. He is responsible for research and extension duties associated with tropical fruit. Dr. Crane can be reached at: TREC, 18905 SW $280^{\text {th }}$ St., PO Box 111569 , Homestead, FL 33031-3314, (305) 246-7001, ihcr@gnv.ifas.ufl.edu.

- Michael Aerts is the assistant director of the Environmental and Pest Management Division of the Florida Fruit and Vegetable 
Association. He facilitates communication between commodity groups and regulatory agencies. Mr. Aerts can be reached at: FFVA, 4401 E. Colonial Drive, Box 140155, Orlando, FL 32814, (407) 894-1351, maerts@ffva.com.

- Mark Mossler is a pesticide information specialist for the Food Science and Human Nutrition Department's Pesticide Information Office at the University of Florida's Institute of Food and Agricultural Sciences. He is responsible for providing pesticide information to the public and governmental agencies. Mr. Mossler can be reached at UF/IFAS PIO, Box 110710, Gainesville, FL 32611, (352) 392-4721, mamossler@mail.ifas.ufl.edu.

\section{Acknowledgements}

The following individuals served as reviewers and/or provided information used in the guava and wax jambu profile:

- Carlos F. Balerdi, Extension Agent III, Fruit Crops, Multi-County, Dade County, Homestead;

- Robert T. Mcmillan Jr, Professor, Subtropical Fruits and Vegetables, University of Florida, Tropical Reseach and Education Center, Homestead;

- Jorge E. Peña, Professor, Tropical Fruit Entomology, University of FloridaTropical Reseach and Education Center, Homestead;

Support for Florida's Crop/Pest Management Profile project and this publication was provided by a Pest Management Centers grant from the USDA-CSREES.

\section{References}

1. Markle, G.M., Baron, J.J., and Schneider, B.A. Food and Feed Crops of the United States. June 1998. Meister Publishing Company, Willoughby, $\mathrm{OH}$.

2. Degner, R.L., Moss, S.D., and Mulkey, W.D. August 1997. University of Florida, Institute of Food and Agricultural Sciences Report:

Economic Impact of Agriculture and Agribusiness in Dade County, Florida. Florida Agricultural Market Research Center Industry Report 97-1. Gainesville, FL.

3. Crane, J.H. 1996. Tropical Fruit Crops Acreage in Florida. University of Florida, Institute of Food and Agricultural Sciences, TREC, Homestead, FL.

4. Malo, S.E. and Campbell, C.W. April 1994. The Guava. Horticultural Sciences Department Fact Sheet HS-4. Florida Cooperative Extension Service, Institute of Food and Agricultural Sciences, University of Florida. Available: http://edis.ifas.ufl.edu/MG045.

5. Tropical Fruit Growers of South Florida, Inc., Homestead, FL. Available: http://www.flag.com/tropical/waxjambu.htm.

6. Personal communication with J.H. Crane, TREC, Homestead, FL. October, 2001.

7. Pena, J. and Johnson, F. November 2001. Insect Management in Guava. Document ENY412. Florida Cooperative Extension Service, Institute of Food and Agricultural Sciences, University of Florida. Available: http://edis.ifas.ufl.edu/IG072.

8. Denmark, H.A. and Wolfenbarger, D.O. July 1999. Redbanded Thrips. Department of Entomology and Nematology, University of Florida, and Florida Department of Agriculture and Consumer Services, Division of Plant Industry Featured Creatures web site.

Available:

http://creatures.ifas.ufl.edu/orn/thrips/redbanded thrips.htm. 
9. Weems, H.V. and Heppner, J.B. March 2001. Caribbean Fruit Fly. Department of Entomology and Nematology, University of Florida, and Florida Department of Agriculture and Consumer Services, Division of Plant Industry Featured Creatures web site.

Available:

http://creatures.ifas.ufl.edu/fruit/tropical/caribbe an fruit fly.htm.

10. Hamon, A.B. September 2000. Cardin's Whitefly. Department of Entomology and Nematology, University of Florida, and Florida Department of Agriculture and Consumer Services, Division of Plant Industry Featured Creatures web site. Available: http://creatures.ifas.ufl.edu/fruit/cardins wfly.ht $\underline{\mathrm{m}}$.

11. DPRA. March 2001. AGCHEMPRICE, Current U.S.A. Prices of Non-Fertilizer Agricultural Chemicals. Summary Edition. DPRA Incorporated, Manhattan, KS.

12. Gowan labels. Available: http://www.cdms.net/manuf/mprod.asp? $\mathrm{mp}=9$

13. Knapp, J.L. February 1999. Citrus Commodity: A Biologic and Economic Assessment of Pesticide Usage. USDA National Agricultural Pesticide Impact Assessment Program Report No. 1-CA-99.

14. Weed Science Society of America. 1994. Herbicide Handbook - $7^{\text {th }}$ Edition.

15. Futch, S.H. and Singh, M. October 2000. 2001 Florida Citrus Pest Management Guide: Weeds. Fact Sheet HS107. Florida Cooperative Extension Service, Institute of Food and Agricultural Sciences, University of Florida. Available: http://edis.ifas.ufl.edu/CG013.

16. Monsanto Company labels. Available: http://www.cdms.net/manuf/mprod.asp? $\mathrm{mp}=13$ 7.
17. Simone, G.W. July 1999. Disease Management in Guava (Psidium spp.). Florida Cooperative Extension Service, Institute of Food and Agricultural Sciences, University of Florida. Available: http://edis.ifas.ufl.edu/PG012.

18. Griffin 2000 Agricultural Product Reference Guide, Griffin L.L.C., Valdosta, GA.

19. McSorley, R. and Parrado, J.L. 1982. Spatial Arrangement of Nematodes Around Four Species of Tropical Fruit Trees. Nematropica. Vol. 12, No. 2.

20. McSorley, R. 1992. Nematological Problems in Tropical and Subtropical Fruit Tree Crops. Nematropica. Vol. 22, No. 1. 